\title{
POTENTIAL ANTI-TUMOR AND ANTI-INFLAMMATORY ACTIVITY OF SIX MISTLETOE PLANTS IN THE FAMILY VISCACEAE PRESENT IN WESTERN GHATS, INDIA
}

\author{
RAMADASAN KUTTAN ${ }^{*}$, SHIVAMURTHY G.R. ${ }^{2}$, GIRIJA KUTTAN ${ }^{3}$
}

${ }^{1}$ Amala Cancer Research Centre, Amala Nagar P. 0, Thrissur 680555, Kerala, India, ${ }^{2}$ Controller of Examinations, JSS College for Women Saraswathypuram, Mysore 670 009, 3Department of Immunology, Amala Cancer Research Centre, Amala Nagar P. 0, Thrissur 680555, Kerala, India

Email: grsgyarahally@gmail.com

Received: 06 Jun 2017 Revised and Accepted: 21 Sep 2017

\section{ABSTRACT}

Objective: To find out the cytotoxicity, anti-tumor and anti-inflammatory activities of six species of plants belongs to Viscaeceae family available in Western Ghats (India).

Methods: Cytotoxicity of Viscum extracts was studied by trypan blue exclusion and MTT assay using various cell lines. Anti-tumor activity was determined using Ehrlich ascites carcinoma (EAC) and Dalton's lymphoma ascites (DLA) cells in mice. Anti-inflammatory activities of Viscum extracts were studied using carrageenan and dextran induced mouse paw edema models.

Results: Viscaeceae plant extracts studied were cytotoxic towards transformed cells DLA and EAC as well as to MCF-7, MDA-MB-231 and SKBR3 cell lines. Extracts of $V$. orientale, $V$. nepalense and $V$. ramosissimum, $V$. trilobatum were cytotoxic towards normal cells while $V$. angulatum and $V$. capitellatum were found to be nontoxic. Excepting $V$. angulatum all the other species selected here showed toxicity to animals. Administration of nontoxic concentration of extracts of Viscaeceae plants significantly $(\mathrm{P}<0.001)$ increased the lifespan of ascites tumor bearing animals and reduced DLA cells induced solid tumor development. All these plants except $V$. capitallatum and $V$. trilobatum showed significant $(\mathrm{P}<0.001)$ antiinflammatory activity against carrageenan and dextran models and reduced pro-inflammatory cytokine levels.

Conclusion: Four plants of Viscum species studied were cytotoxic to tumour cells and inhibited tumour development. Of the six species studied $V$. angulatum was non-toxic to animals and showed maximum efficiency as an antitumour agent. These plants showed significant anti-inflammatory activity and reduced inflammatory markers.

Keywords: Semiparasitase plants, Viscum species, Tumour reducing activity, Anti-inflammatory activity, Pro-inflammatory cytokines

(C) 2017 The Authors. Published by Innovare Academic Sciences Pvt Ltd. This is an open access article under the CC BY license (http://creativecommons.org/licenses/by/4.0/) DOI: http://dx.doi.org/10.22159/ijpps.2017v9i11.20541

\section{INTRODUCTION}

Viscum is a genus of about 70-100 species of mistletoes, native to temperate and tropical regions of Europe, Africa, Asia and Australasia. Mistletoes constitute the predominant group of angiosperm shoot or stem hemi parasites, which grow on the branches of host trees or shrubs and take water, water-conducted nutrients and organic solutes from the host's vasculature. Historically speaking, mistletoe was considered as an antidote for poisons as well as a remedy for barrenness and constipation [1]. Rudolf Steiner, the founder of anthroposophical medicine, introduced mistletoes for cancer treatment [2]. Significant work has been done on one of the species of Viscaceae family, Viscum album L. which grows in European countries. Iscador, an aqueous extract of $V$. album. has been widely used as an anti-cancer drug for several decades [3]. Anti-tumor [4], anticarcinogenic [5], anti-metastatic [6], chemo and radio protective activities [7] of V. album have been reported. V. album contains several active components such as mistletoe lectins [8] viscotoxins [9], alkaloids [10] and polysaccharides [11] which are reported to show anti-tumor properties by causing cell cycle delay or arrest and induction of apoptosis [12]. It inhibits tumor angiogenesis [13, 14] and exert immune-potentiating activities that enhance the host defense system against tumors $[15 ; 16]$. Compounds of mistletoe origin are also been reported to show in vitro inhibitory potential on multidrug resistance protein (MDR1) [17]. The analysis of clinical studies suggests that adjuvant treatment of cancer patients with mistletoe extracts is associated with a better survival, a reduction of side effects of conventional therapy and with an increase of quality of life [18-21].

No systematic work has been done on semi-parasitic plants other than Viscum album. In the present study six plants belonging to the family Viscaceae viz Viscum orientale Wild, Viscum nepalense Spring, Viscum ramosissimum Wall and Viscum angulatum Heyne ex DC Viscum capitallatum Sm and Viscum trilobatum Talbot collected from
Western Ghats, India were checked for their anti-tumour and antiinflammatory activity. $V$. orientale is a large hemi-parasitic, much branched shrub with opposite and oblanceolate leaves. Flowers are produced in dichasial cymose triad clusters developing into ovoid to sub-globose berry. The plant is reported to have medicinal applications mainly in neuralgia, diabetes and in the treatment of itching [22]. V. nepalense is a leafless hemi-parasitic mistletoe found growing on the branches of various trees. The branches are long, flat, with pendulous tufts and internodes being variable in length, usually a trifle wider at the distal end and striate. The leaves are visible only in the very young internodes as small bracts below the flowers. It has been reported that this species possesses a number of therapeutic properties and is used for the treatment of many diseases in traditional medicine [23]. V. ramosissimum is a slender, pendulous, leafless, yellowish-green plant with rounded internodes.

Inflorescence may be dichasia or modified dichasia with pistillate flowers or sometimes solitary representing a reduced dichasium. Sometimes the dichasia are complete, bearing a terminal pistillate flower and two lateral staminate flowers. The berry is ovoid and pale green in colour. $V$. angulatum is a leafless hemiparasitic shrub with four-angled branches which are slightly broadened near the apex of the internode and smooth. Flowers are seen as solitary or in groups either with all female flowers or with a single female flower surrounded by male flowers. Male flowers have four triangular perianth lobes with four epiphyllous stamens with sessile anthers. The ovary is obovoid with a short style in female flowers. The berry is globose and yellowish. This plant is traditionally used in Asian countries for the treatment of hypertension [24]. Viscum capitellatum and Viscum trillobatum are hyper coparasities. Former growing on Dendropnthoe falcota (parasitic plant on Terminalia tomento) and Viscum trillobatum growing on Macrosoten capitellata (parasitic plant on Mangifera indica). Viscum trillobatum is an 
evergreen plant grows up to $25 \mathrm{~cm}$ long. The present work was aimed to determine cytotoxic, anti-tumor and anti-inflammatory activities of the plants of the Viscaceae present in Western Ghats in India along with their toxicity profiles.

\section{MATERIALS AND METHODS}

\section{Animals}

Swiss albino mice (male, 4-6 w old, 20-25 g b. wt) were obtained from small Animal breeding station, Kerala Veterinary University, Thrissur. The animals were kept in ventilated cages in air-controlled room and fed with mouse chow-(Krish Scientfic Shopee, Bangalore, India) and water ad libitum. All animal experiments were performed as per the instructions prescribed by the Committee for the Purpose of Control and Supervision of Experiments on Animals (CPCSEA) (No.149/PO/ Rc/S/1999/CPCSEA), Ministry of Environment and Forest, Government of India, and implemented through the Institutional Animal Ethical Committee of Amala Cancer Research Centre.

\section{Chemicals}

Minimum Eagle's Medium (MEM) was purchased from Hi-Media, Mumbai, India. Fetal calf serum was purchased from Biological Industries, Israel. Carrageenan, dextran and 3-(4, 5-dimethylthiazol2-yl)-2,5-diphenyltetrazolium bromide (MTT) were purchased from Sigma Chemicals, St. Louis, USA. All other chemicals used were of analytical reagent grade.

\section{ELISA kits}

Highly specific ELISA kits for Interleukin-1 $\beta$ (IL-1 $\beta$ ), Interleukin6 (IL-6), C-reactive protein (CRP), and tumor necrosis factor- $\alpha$ $(\mathrm{TNF}-\alpha)$ were purchased from Pierce Biotechnology (RockfordIllinois, USA).

\section{Cell lines}

Transformed cells, L929 (murine lung fibroblast cell line), MCF-7 (human breast cancer cell line), and MDA-MB-231(human breast cancer cell line) were obtained from National Cell Science Centre, Pune, India and maintained in MEM supplemented with $10 \%$ fetal calf serum (FCS) and antibiotics. Ehrlich ascites carcinoma (EAC) and DLA cells were originally procured from Adayar Cancer Institute, Chennai, India and were maintained in the peritoneal cavity of Swiss albino mice. Sheep red blood cells (SRBC) were collected from a local slaughter house and preserved in Alsever's solution

\section{Collection of plants and their identification}

Hemi-parasitic sub-herbs in the family Viscaceae were collected as per Good Collection practice from the Chammundi Hills, Bandipur forest area Mysore as well as from Belgam, India. Identification of the plants was done by Dr. Shivamurthy, G. R, Controller of Examinations, JSS College for Women, Saraswathypuram, Mysore. The species of plants and their host trees are given in table 1.

Table 1: Name of plants, their host trees

\begin{tabular}{ll}
\hline Plants & Host tree \\
\hline Viscum orientale Wild & Pongamia pinnata \\
Viscum nepalense Spiens & Zizyphus oenoplea \\
Viscum ramosissimum Well & Ficus bengalensis \\
Viscum angulatum Heyneex DC & Schrebera swietenioides \\
Viscum capitallatum Sm & Terminalia tomentosa \\
Viscum trilobatum Talbot & Mangifera indica \\
\hline
\end{tabular}

Photograph of the plants collected are given in fig. 1.

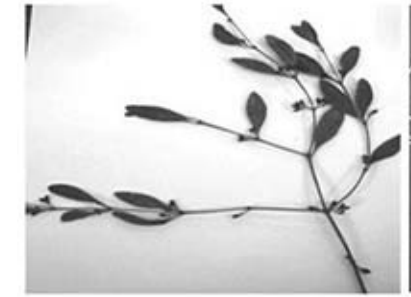

Viscum orientale

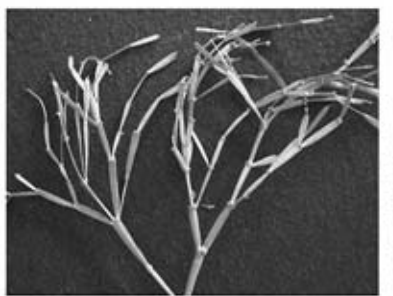

Viscum nepalense

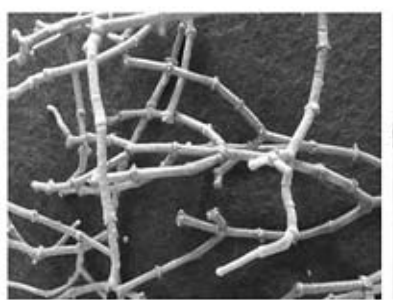

Viscum ramossimium

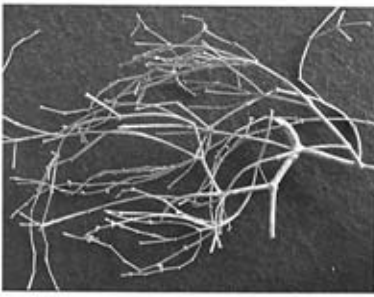

Viscum angulatum

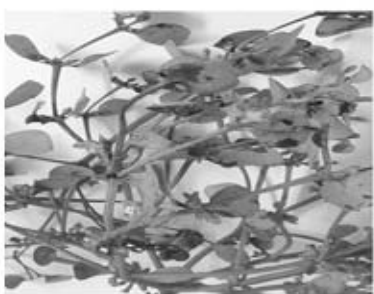

Viscum trilobatum

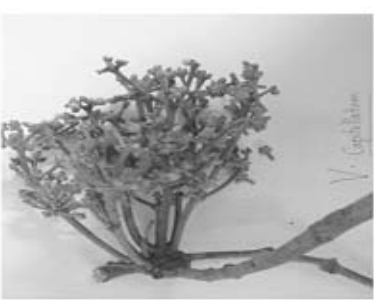

Viscum capitellatum

Fig. 1: Photos of six hemi-parasitic sub-herbs in the family Viscaceae collected from Western Ghats 


\section{Preparation of aqueous extract}

Plants were washed in running water, rinsed with autoclaved double distilled water, air dried and powdered. Aqueous extracts of each plant were prepared by mixing $10 \mathrm{~g}$ of plant powder with $100 \mathrm{ml}$ of autoclaved double distilled water and stirred overnight. The supernatant obtained by centrifugation was dried by lyophilisation.

\section{Determination of in vitro cytotoxicity of aqueous extracts of Viscaceae species}

In vitro cytotoxic activity of the extracts of Viscaceae species was determined by the trypan blue dye exclusion method [25]. Tumor cells DLA and EAC $\left(1 \times 10^{6}\right.$ cells $\left./ 0.1 \mathrm{ml}\right)$ were mixed with different concentrations $(10-500 \mu \mathrm{g} / \mathrm{ml})$ of the plant extracts and incubated for $3 \mathrm{~h}$ at $37^{\circ} \mathrm{C}$. After incubation, $0.1 \mathrm{ml}$ of $1 \%$ trypan blue solution was added to each tube mixed well and kept for 2-3 min and loaded on a haemocytometer. Viable cells exclude trypan blue dye, while non-viable cells take up the dye and thus appear blue in colour. The number of stained and unstained cells was counted separately and percentage cell death was determined using the formula

$$
\% \text { of Cell death }=\frac{\text { Number of dead cells }}{\text { Total number of cells }} \times 100
$$

Determination of the effect of aqueous extracts of Viscaceae species on viability of different transformed cells by MTT assay

The effect of the aqueous extracts on the viability of different transformed cells was determined using MTT assay [26-27]. Tumor cell lines L929, MCF-7 and MDA-MB-231 $\left(5 \times 10^{3}\right.$ cells/well $)$ were seeded in 96 well flat bottom plates and incubated for $24 \mathrm{~h}$ at $37^{\circ} \mathrm{C}$ under $5 \% \mathrm{CO}_{2}$ atmosphere. After incubation, different concentrations of plant extracts $(5-50 \mu \mathrm{g} / \mathrm{ml})$ were added to the wells and the incubation was continued for $48 \mathrm{~h}$ with or without plant extracts.

The medium was aspirated $4 \mathrm{~h}$ before the completion of incubation and $20 \mu \mathrm{l}$ of MTT $(5 \mathrm{mg} / \mathrm{ml})$ solution was added to each well and incubated at $37^{\circ} \mathrm{C}$ for $2 \mathrm{~h}$. After incubation, plates were centrifuged, supernatant was removed and $100 \mu \mathrm{l}$ of DMSO was added to each well. The plates were then incubated at room temperature for $15 \mathrm{~min}$ and the optical density was measured at $570 \mathrm{~nm}$. Percentage viability was expressed as (Abs $(570 \mathrm{~nm})$ of untreated wells-

$\%$ Cell viability $=100-\left(\frac{A 570 \mathrm{~nm} \text { of untreated cells }-A 570 \mathrm{~nm} \text { of treated wells }}{A 570 \mathrm{~nm} \text { of untreated cells }} \times 100\right)$

\section{Toxicity studies of Viscum extracts in animals}

Swiss albino mice were used for this study. Different groups of mice (6 mice/group) were treated intraperitoneally with a single dose of an extract of $V$. orientale, $V$. nepalense, $V$. ramosissimum and $V$. angulatum extracts, $V$. capitallatum and $V$. trillobatum at concentrations $330 \mathrm{mg} / \mathrm{kg}$ b. wt, $115 \mathrm{mg} / \mathrm{kg} \mathrm{b}$. wt, $58 \mathrm{mg} / \mathrm{kg}$ b. wt, $33 \mathrm{mg} / \mathrm{kg} \mathrm{b}$. wt, $16 \mathrm{mg} / \mathrm{kg}$ b. wt respectively and all the animals were monitored for one month for change in body weight, mortality and any adverse reactions.

In another experiment $V$. orientale, $V$. nepalense, $V$. ramosissimum, $V$. angulatum. V. capitallatum and Vtrillobatum extracts at doses of 16 $\mathrm{mg} / \mathrm{kg} \mathrm{b}$. wt, $8 \mathrm{mg} / \mathrm{kg} \mathrm{b}$. wt and $3.3 \mathrm{mg} / \mathrm{kg} \mathrm{b}$. wt. were administered intraperitoneally for 5 consecutive days and the body weight, mortality and any adverse reaction were monitored for one month.

Determination of the effect of Viscum species on EAC cells induced ascites tumor development

Swiss albino mice were divided to eight groups ( $\mathrm{n}=10$ /group). All of the animals were injected intraperitoneally with $1 \times 10^{6}$ EAC cells to induce ascites tumor. Animals in group I were inoculated with EAC cells alone and kept as untreated control. Animals in group 2-6 were treated with different Viscum extracts $3.3 \mathrm{mg} / \mathrm{kg}$. in the case of $V$. orientale, $V$. nepalense, $V$. ramosissimum, $V$. Capitollatum and $V$. trillobatum and 8 and $16 \mathrm{mg}$ for $V$. angulatum for 10 consecutive days. The death pattern of animals due to the tumor burden was noted and the percentage increase in life span was calculated using the formula

$$
\% \text { Increase in life } \operatorname{span}=\frac{T-C}{C} \times 100
$$

Where ' $\mathrm{T}$ ' represent the number of days extract treated animals survived and ' $C$ ' represent the number of days tumor control animals survived [28].

Determination of the effect of Viscum species on DLA cells induced solid tumor development

Swiss albino mice were divided into eight groups ( $\mathrm{n}=10 /$ group). Solid tumor was induced by injecting DLA cells $\left(1 \times 10^{6} \mathrm{cells} /\right.$ animal $)$ subcutaneously into the right hind limbs of animals in all groups. Animals in group I were kept as tumor control. Animals in groups 28 were treated with different Viscum extracts for 10 consecutive days (concentration as given above). The radii of developing tumors were measured from two directions using vernier calipers at three day intervals for one month and tumor volume was calculated using the formula

$$
\text { Tumor volume }(V)=\frac{4}{3} \pi r_{1}^{2} \times r_{2}
$$

Where ' $r_{1}$ ' and ' $r_{2}$ ' represent the major and minor diameter, respectively [29].

Determination of anti-inflammatory activity of Viscum species against carrageenan induced inflammatory model

Swiss albino mice were divided in to 6 groups. Animals in group 1 were kept as untreated control. Animals in group 2-6 were treated with different concentrations of Viscum extracts for five consecutive days. Acute inflammation was induced by injecting $50 \mu \mathrm{l}$ of freshly prepared $1 \%$ suspension of carrageenan in normal saline on sub plantar region of the right paw of mice one hour after the last dose of extract administration [30]. The paw thicknesses of all the animals were measured using a vernier caliper before and after carrageenan injection and continued for $6 \mathrm{~h}$ with 1 hour intervals followed by 24 and $48 \mathrm{~h}$.

The percentage inhibition of paw thickness was calculated using the formula:

$\%$ Inhibition of paw thickness $=\frac{(t C n-t C o)-(t T n-t T o) \times 100}{t C n-t C o}$

Where $\mathrm{tCn}=$ paw thickness at particular time point of control animal; $\mathrm{tC} 0=$ paw thickness before induction; $\mathrm{tTn}=$ paw thickness at particular time point of treated animal; and tT $0=$ paw thickness before induction.

Determination of anti-inflammatory activity of aqueous extracts of Viscum species against dextran induced acute inflammatory model

Swiss albino mice were divided into 8 groups (6 animals/group). Animals in group 1 were kept as untreated control. Animals in group 2-6 were treated with Viscum extracts (i. p) for five consecutive days. Acute inflammation was induced by injecting $50 \mu \mathrm{l}$ of freshly prepared $1 \%$ suspension of dextran in normal saline on the sub plantar region of the right paw of mice $1 \mathrm{~h}$ after the last dose of extract administration [31]. The paw thickness of all the animals was measured using a vernier caliper before and after dextran injection and continued for $6 \mathrm{~h}$. at $1 \mathrm{~h}$ intervals followed by $24 \mathrm{~h}$ and $48 \mathrm{~h}$. The percentage inhibition of paw thickness was calculated using the formula as mentioned above.

Effect of aqueous extracts of Viscum species on proinflammatory cytokine levels during carrageenan induced paw edema formation

Blood was collected at $3 \mathrm{~h}$ after carragenine injection with and without treatment and Serum was separated from animals in the above experiment and used for the estimation of various proinflammatory cytokines (TNF- $\alpha$, IL- $1 \beta$, and IL- 6 ) by ELISA method NO estimation was done by Griess reagent method [32].

\section{Statistical analysis}

The values are expressed as mean \pm standard deviation (SD). The mean values were statistically analyzed by one way analysis of variance (ANOVA) followed by appropriate post hoc test (Dunnett's 
multiple comparison test) using Graph pad Instat 3 Software (Graph Pad Software, Inc. La Jolla, California, USA). Significant levels of control groups were determined by comparing with those of normal group, whereas significant levels of Viscum-treated groups were determined by comparing with those of control groups. P value $<0.05$ was considered to be statistically significant. The P-value considered as significant are indicated by “*”, “**” and "***” for $\mathrm{p}<0.05, \mathrm{p}<0.01$ and $\mathrm{p}<0.001$ respectively.

\section{RESULTS}

\section{Yield of the extract}

The extracted solid yield from $V$. orientale was $3 \mathrm{gm}, V$. nepalense 1.5 $\mathrm{gm}, V$. ramosissimum $5.5 \mathrm{gm}$ and $V$. angulatum $3.2 \mathrm{gm} V$. capitallatum
(3 gm), V. trillobatum (2.6 gm) from $10 \mathrm{gm}$ of the each crude powder.

\section{Cytotoxic acivity of Viscum species on DLA and EAC Cells}

Short term cytotoxicity studies using different Viscum species by trypan blue-dye exclusion assay showed that $V$. orientale, $V$. nepalense, $V$. ramosissimum and $V$. angulatum were cytotoxic to Dalton's lymphoma ascites (DLA) cells. The IC50 value for $V$. orientale was $20 \mu \mathrm{g} / \mathrm{ml}$, for $V$. nepalense was $15 \mu \mathrm{g} / \mathrm{ml}$, for $V$. ramosissimum was $17 \mu \mathrm{g} / \mathrm{ml}$ and for $V$. angulatum was $22 \mu \mathrm{g} / \mathrm{ml}$. Aqueous extracts of Viscaceae family also showed cytotoxicity towards Ehrlich ascites (EAC) cells. The IC50 value for $V$. orientale was $35 \mu \mathrm{g} / \mathrm{ml}$, for $V$. nepalense was $19 \mu \mathrm{g} / \mathrm{ml}$, for V. ramosissimum was $90 \mu \mathrm{g} / \mathrm{ml}$ and for $V$. angulatum was $18 \mu \mathrm{g} / \mathrm{ml}$ (table 2).

Table 2: Cytotoxicity of Viscum extracts on Dalton's Lymphoma ascites (DLA) and Ehrlich carcinoma cells (EAC)

\begin{tabular}{lll}
\hline Viscum plant & IC $_{\mathbf{5 0}}(\boldsymbol{\mu g} / \mathbf{m l})$ & EAC cells \\
\cline { 2 - 3 } & DLA cells & 35 \\
Viscum orientale & 20 & 19 \\
Viscum nepalense & 15 & 90 \\
Viscum ramosisimium & 17 & 18 \\
Viscum angulatum & 22 & $>250$ \\
Viscum capitellatum & $>500$ & $>500$ \\
Viscum trilobatum & $>500$ & \\
\hline
\end{tabular}

Compared to other Viscum species, $V$. capitallatum and $V$. trilobatum were less ctotoxic. IC 50 of $V$. capitallatum extract to DLA cells was $>500 \mu g$ and EAC cells was $>250 \mu \mathrm{g} / \mathrm{ml}$. In the case of $V$. tribolatum IC $_{50}$ to DLA and EAC cells were more than $500 \mu \mathrm{g} / \mathrm{ml}$

\section{Cytotoxic acivity of Viscum species to cancer cells in culture}

$V$. orientale showed cytotoxicity towards transformed cells L929(IC $50=9 \mu \mathrm{g} / \mathrm{ml}$ ), MCF-7 (IC $50=29.5 \mu \mathrm{g} / \mathrm{ml}$ ), MDA-MB-231(IC $50=20$ $\mu \mathrm{g} / \mathrm{ml}$ ) and SKBR3 (IC $50=12 \mu \mathrm{g} / \mathrm{ml}$ ). V. nepalense showed cytotoxicity towards transformed cells L929 (IC $50=13 \mu \mathrm{g} / \mathrm{ml}$ ), MCF-7 (IC 50= $17 \mu \mathrm{g} / \mathrm{ml}$ ), MDA-MB-231(IC $50=15 \mu \mathrm{g} / \mathrm{ml}$ ) and SKBR3 (IC $50=10 \mu \mathrm{g} / \mathrm{ml}$ ). V. ramosissimum showed cytotoxicity towards transformed cells L929 (IC $50=23 \mu \mathrm{g} / \mathrm{ml}$ ). MCF-7 (IC 50= $26 \mu \mathrm{g} / \mathrm{ml}$ ), MDA-MB-231 (IC $50=22 \mu \mathrm{g} / \mathrm{ml}$ ) and SKBR3 (IC $50=14$ $\mu \mathrm{g} / \mathrm{ml}$ ). V. angulatum showed cytotoxicity towards transformed cells
L929 (IC $50=20 \mu \mathrm{g} / \mathrm{ml}$ ), MCF-7 (IC $50=42 \mu \mathrm{g} / \mathrm{ml}$ ), MDA-MB-231(IC $50=28 \mu \mathrm{g} / \mathrm{ml}$ ) and SKBR3 (IC $50=20 \mu \mathrm{g} / \mathrm{ml}$ ). Compared to other extracts $V$. capitallatum and $V$. trilobatum extracts were less cytotoxic to cancer cells. $\mathrm{IC}_{50}$ to all the cells studied were more than $25 \mathrm{ug} / \mathrm{ml}$.

$V$. orientale, $V$. nepalense, $V$. ramosissimum and $V$. capitallatum also showed cytotoxicity towards normal cell like Vero cells. However, $V$. angulatum showed selective cytotoxicity towards transformed cells and no toxicity was observed to normal cells (table 3).

Table 3: Comparative cytotoxicity of different Viscum extracts to transformed cells and normal cells

\begin{tabular}{|c|c|c|c|c|c|}
\hline \multirow[t]{3}{*}{ Viscum plants } & \multicolumn{5}{|c|}{ IC50 $(\mu \mathrm{g} / \mathrm{ml})$} \\
\hline & \multicolumn{3}{|c|}{ Transformed cells } & \multicolumn{2}{|c|}{ Normal cells } \\
\hline & L929 cells & MCF-7cells & MDA-MB-231cells & SKBR3 & Vero cells \\
\hline Viscum orientale & 9 & 29.5 & 20 & 11.5 & $>50$ \\
\hline Viscum nepalense & 12.5 & 17 & 15 & 10 & $>50$ \\
\hline Viscum ramosissimium & 22.5 & 25.5 & 22 & 14 & $>50$ \\
\hline Viscum angulatum & 20 & 42 & 27.5 & 20 & Non-toxic \\
\hline Viscum capitellatum & $>25$ & $>25$ & $>25$ & $>25$ & $>25$ \\
\hline Viscum trilobatum & $>25$ & $>25$ & $>25$ & $>25$ & Non-toxic \\
\hline
\end{tabular}

\section{Toxicity of Viscum extracts}

Administration of aqueous extracts (single dose) of $V$. orientale, $V$. nepalense, $V$. ramosissimum and $V$. trilobattum at different concentrations such as $330,115,58,33 \mathrm{mg} / \mathrm{kg}$ b. wt showed observable toxicity including weight loss and mortality. All animals treated with $V$. orientale and $V$. ramosissimum died within $9 \mathrm{~d}$. $V$. nepalense treated animals died within $12 \mathrm{~d}$. Similarly all the animals treated with $V$. trilobattum died within 5 d. $V$. capitallatum was less toxic. V. angulatum treated groups did not show mortality or any adverse effects even at concentrations of $330 \mathrm{mg} / \mathrm{kg} \mathrm{b}$. wt.

In another study, lower concentrations of Viscum extracts like 3.3, 8 and $16 \mathrm{mg} / \mathrm{kg} \mathrm{b}$. wt were given to mice for 5 consecutive days and all the animals were monitored for $1 \mathrm{mo}$. All the animals treated with $V$. orientale and $V$. ramosissimum at a concentration of $16 \mathrm{mg} / \mathrm{kg} \mathrm{b}$. wt died within $4 \mathrm{~d}$ and $V$. nepalense treated animals died within $15 \mathrm{~d}$. Viscum capitallatum treated animals did not show any toxicity (up to $58 \mathrm{mg} / \mathrm{kg}$ ) while $V$. trilobatum showed toxicity at $33 \mathrm{mg} / \mathrm{kg}$. body weight. Although there was a reduction in body weight, animals treated continuously with all the Viscum extracts at a concentration of $8 \mathrm{mg} / \mathrm{kg} \mathrm{b}$. wt did not show mortality. Continuous administration of $V$. orientale, $V$. nepalense and $V$. ramosissimum at a concentration of $3.3 \mathrm{mg} / \mathrm{kg}$ b. wt showed significant increase in body weight and there was no mortality of animals. So further in vivo studies using $V$. orientale, $V$. nepalense and $V$. ramosissimum were done using 3.3 $\mathrm{mg} / \mathrm{kg} \mathrm{b}$. wt. of the extracts. Continuous administration of $V$. angulatum to mice at concentrations $3.3,8$ and $16 \mathrm{mg} / \mathrm{kg} \mathrm{b}$. wt for 5 consecutive days did not show any mortality, body weight reduction or any other adverse effects. Thus concentrations of 8 and $16 \mathrm{mg} / \mathrm{kg}$. b. wt. were used for in vivo studies with $V$. angulatum.

\section{Effect of Viscum species on ascites tumor development}

All the Viscum species studied except $V$. orientale showed profound antitumor effect against EAC cells induced ascites tumor model. Percentage increase in life span of ascites tumor bearing mice by $V$. nepalense (3.3 $\mathrm{mg} / \mathrm{kg} \mathrm{b}$. wt) was $43 \%$, by $V$. ramosissimum was $35 \%$ (3.3 mg/kg b. wt) and by $V$. angulatum were $32 \%(8 \mathrm{mg} / \mathrm{kg} \mathrm{b}$. wt) and $56 \%(16 \mathrm{mg} / \mathrm{kg} \mathrm{b}$. wt) (table 4). 
Table 4: Effect of Viscum extracts on ascites tumour development in mice

\begin{tabular}{|c|c|c|}
\hline Groups & Mean survival days & \% increase in life span \\
\hline Control & $16.8 \pm 1.4$ & - \\
\hline Viscum orientale $(3.3 \mathrm{mg} / \mathrm{kg} \mathrm{b.} \mathrm{wt})$ & $18.3 \pm 1.2^{* *}$ & 9.12 \\
\hline $\begin{array}{l}\text { Viscum nepalense } \\
(3.3 \mathrm{mg} / \mathrm{kg} \mathrm{b} . \mathrm{wt})\end{array}$ & $22.17 \pm 1^{* *}$ & 42.8 \\
\hline $\begin{array}{l}\text { Viscum ramossimium } \\
(3.3 \mathrm{mg} / \mathrm{kg} \mathrm{b} . \mathrm{wt})\end{array}$ & $22.67 \pm 1.4^{* *}$ & 34.9 \\
\hline $\begin{array}{l}\text { Viscum angulatum } \\
(8 \mathrm{mg} / \mathrm{kg} \mathrm{b} . \mathrm{wt})\end{array}$ & $22.17 \pm 1^{* *}$ & 31.9 \\
\hline $\begin{array}{l}\text { Viscum angulatum } \\
(16 \mathrm{mg} / \mathrm{kg} \mathrm{b} . \mathrm{wt})\end{array}$ & $26.16 \pm 1.6^{* *}$ & 55.72 \\
\hline Viscum capitallatum & $20 \pm 2.19$ & 23.76 \\
\hline Viscum trilobatum & $17.83 \pm 1.83$ & 10.33 \\
\hline
\end{tabular}

Values are mean \pm SD. Values were statistically analysed using one-way ANOVA followed by Dunnett multiple comparison test. ns-Not significant $(\mathrm{p}>0.05),{ }^{*} \mathrm{p}<0.05$; ${ }^{* *} \mathrm{p}<0.01$ significantly, Mean survival in the use of $V$. capitalatum $(16 \mathrm{mg} / \mathrm{kg})$ was $20 \mathrm{~d}$ while that of $V$. trilobatum $(8 \mathrm{mg} / \mathrm{kg}) \mathrm{with}$ $18 \mathrm{~d}$ which were not significant.

\section{Effect of Viscum species on solid tumor development}

The solid tumor volume of mice treated with $V$. orientale, $V$. nepalense, $V$. ramosissimum and $V$. angulatum were found to be significantly lower than that of untreated controls. The tumor volume of the untreated control on the $30^{\text {th }}$ day was $3.11 \mathrm{~cm}^{3}$ whereas the tumor volume of animals treated with $V$. orientale was $1.07 \mathrm{~cm}^{3}, V$. nepalense $0.43 \mathrm{~cm}^{3}$, V. ramosissimum $1.42 \mathrm{~cm}^{3}$ and V. angulatum was 0.337 $\mathrm{cm}^{3} \mathrm{on} 30^{\text {th }}$ day. In the case of $V$. capillatum and $V$. trillobatum tumour volume are day 30 was $2.4 \mathrm{~cm}^{3}$ and $2.5 \mathrm{~cm}^{3}$ which was not significant. V. angulatum showed highest anti-tumor activity i.e. $89 \%$ reduction in the tumor volume on $30^{\text {th }}$ day (fig. 2).

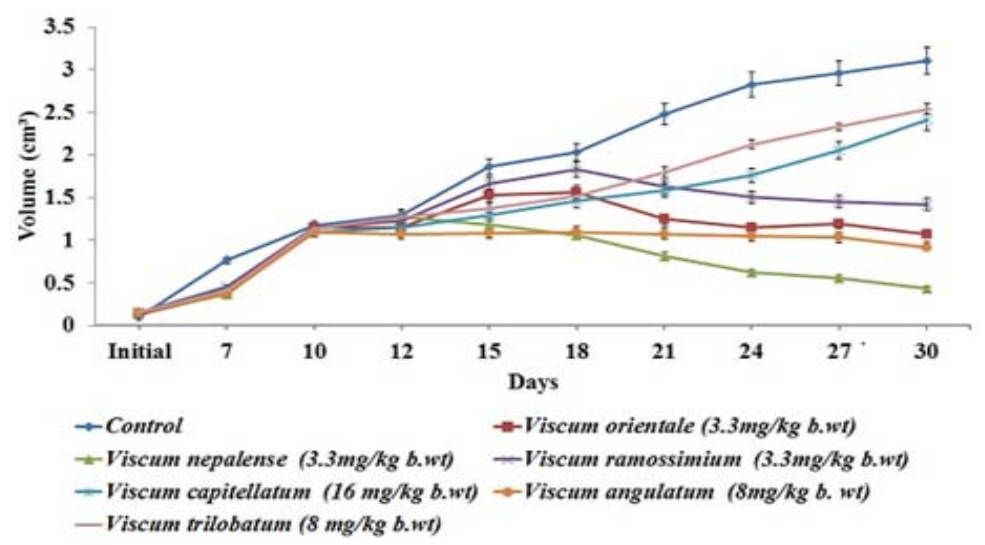

Fig. 2: Anti-tumor effect of Viscum extracts on solid tumor development, (Values are mean \pm SD of six animals)

Effect of Viscum species on carrageenan induced inflammation model

Subplantar injection of carrageenan produced a progressive swelling of paw reaching a maximal paw thickness of $0.411 \mathrm{~cm}$ in the control group at $3^{\text {rd }}$. Treatment with Viscum extracts showed a significant reduction in paw edema induced by carrageenan. Administration of $V$. orientale produced $30 \%$ reduction in paw edema at $3 \mathrm{rd}$ h. $V$. nepalense produced $40 \%$ reduction in paw edema at $3^{\text {rd }} h$. $V$. ramosissimum produced $33.5 \%$ reduction in paw edema at $3 \mathrm{rd} \mathrm{h}$ and $V$. angulatum $(16$ $\mathrm{mg} / \mathrm{kg} \mathrm{b.} \mathrm{wt)} \mathrm{produced} 56.5 \%$ reduction in paw edema at $3^{\text {rd }} \mathrm{h}$ (fig. 3) indicating maximum inhibition of paw edema formation was observed in the animals treated with $16 \mathrm{mg} / \mathrm{kg}$ b. wt of $V$. angulatum. V. capitallatum and $V$. trilobatum extracts did not produce any significant reduction in the inflammation.

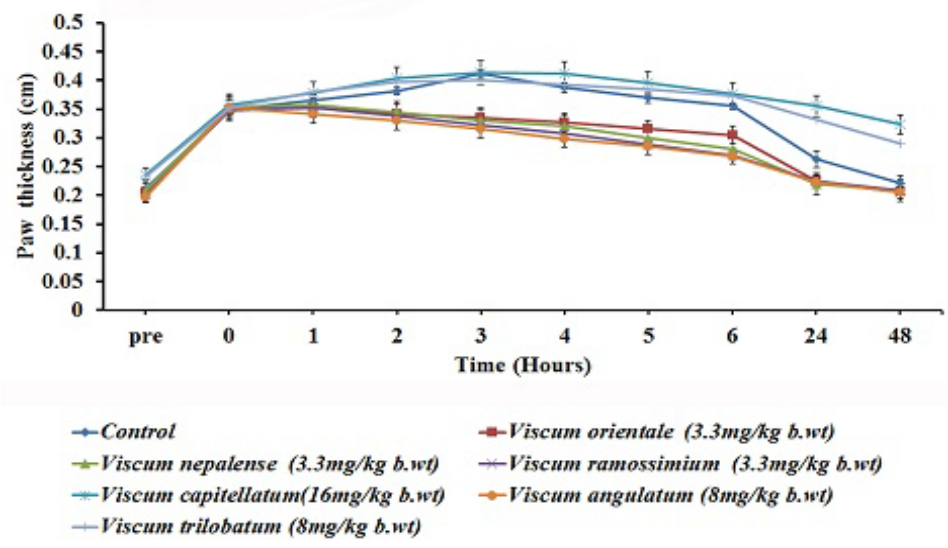

Fig. 3: Anti-inflammatory effect of Viscum extracts on carrageenan induced inflammatory model, (Values are mean \pm SD of six animals) 


\section{Effect of Viscum species on dextran induced inflammation model}

When dextran was used as an inflammatory agent, the control animal showed a maximum paw thickness of $0.415 \mathrm{~cm}$ at the $3^{\text {rd }} \mathrm{h}$. Treatment with Viscum extracts showed a significant reduction in paw edema induced by dextran. Administration of $V$. orientale produced $39 \%$ reduction in paw edema at $3^{\text {rd }}$ h. $V$. nepalense produced $39.0 \%$ reduction in paw edema at $3^{\text {rd }}$ h. $V$. ramosissimum produced $33 \%$ reduction in paw edema at $3^{\text {rd }} \mathrm{h}$ and $V$. angulatum (16 $\mathrm{mg} / \mathrm{kg} \mathrm{b.} \mathrm{wt)} \mathrm{produced} \mathrm{maximum} \mathrm{reduction}(43 \%)$ in paw edema at $3^{\text {rd }} \mathrm{h}$ (fig.4). Both V. capitallatum and $V$. trilobatum extracts did not produce any observable anti-inflammatory activity.

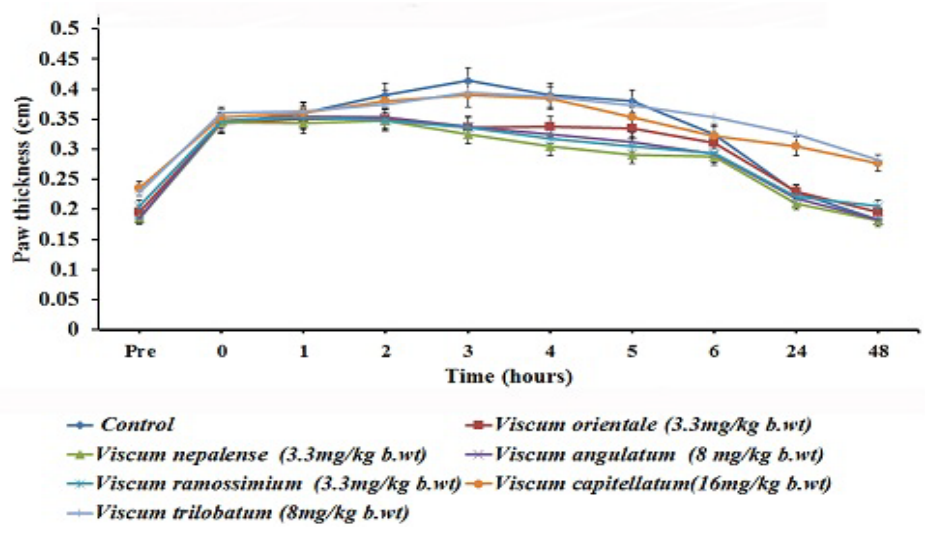

Fig. 4: Anti-inflammatory effect of Viscum extracts on dextran induced inflammatory model, (Values are mean \pm SD of six animals)

Effect of Viscum species on the levels of pro-inflammatory cytokines and nitric oxide during carrageenan induced inflammatory model

The levels of various pro-inflammatory cytokines like TNF- $\alpha$, IL-1 $\beta$, IL-6 and C-reactive protein (CRP) were markedly increased by the treatment with carrageenan. These increased levels were significantly lowered by the administration of $V$. orientale, $V$. nepalense, V. ramosissimum and V. angulatum (tables 5 and 6).

Similarly Levels of NO were markedly increased by the treatment with carrageenan and the increased levels were lowered to almost normal levels by the administration of $V$. orientale, $V$. nepalense, $V$. ramosissimum and $V$. angulatum (table 7).

Table 5: Effect of Viscum species on TNF- $\alpha$ andIL-1 $\beta$ levels during carrageenan induced paw edema formation

\begin{tabular}{|c|c|c|c|c|c|c|}
\hline & \multicolumn{3}{|c|}{ TNF- $\alpha(\mathrm{pg} / \mathrm{ml})$} & \multicolumn{3}{|c|}{ IL-1 $\beta(\mathrm{pg} / \mathrm{ml})$} \\
\hline & Initial & $3^{\text {rd }} \mathbf{h}$ & $24^{\text {th }} h$ & Initial & $3^{\text {rd }} \mathbf{h}$ & $24^{\text {th }} h$ \\
\hline Control & $22.3 \pm 0.8$ & $272.5 \pm 5.2$ & $33.3 \pm 3.9$ & $18.6 \pm 0.1$ & $49.3 \pm 1.6$ & $22.3 \pm 0.78$ \\
\hline Viscum orientale $(3.3 \mathrm{mg} / \mathrm{kg} \mathrm{b.} \mathrm{wt})$ & $23.4 \pm 0.9$ & $268.2 \pm 4.6^{\mathrm{ns}}$ & $33.4 \pm 3.2^{\text {ns }}$ & $17.2 \pm 2.3$ & $46.9 \pm 3.2^{\text {ns }}$ & $20.9 \pm 1.7^{\mathrm{ns}}$ \\
\hline Viscum nepalense ( $3.3 \mathrm{mg} / \mathrm{kg} \mathrm{b} . \mathrm{wt})$ & $22.2 \pm 0.6$ & $125.6 \pm 3.9^{* * *}$ & $24.2 \pm 4.1^{* * *}$ & $17.2 \pm 1.6$ & $26.6 \pm 2.6^{* * *}$ & $16.3 \pm 1.4^{* * *}$ \\
\hline Viscum ramossimium $(3.3 \mathrm{mg} / \mathrm{kg}$ b. wt) & $21.7 \pm 0.6$ & $166.8 \pm 5.6^{* * *}$ & $25.2 \pm 3.5^{* * *}$ & $16.7 \pm 0.1$ & $34.7 \pm 1.6^{* * *}$ & $19.2 \pm 2.1^{\mathrm{ns}}$ \\
\hline Viscum angulatum $(16 \mathrm{mg} / \mathrm{kg} \mathrm{b.} \mathrm{wt})$ & $22.47 \pm 0.86$ & $140.9 \pm 4.9^{* * *}$ & $22.8 \pm 4.3^{* * *}$ & $17.5 \pm 0.3$ & $31.7 \pm 2.6^{* * *}$ & $18.1 \pm 3.2^{*}$ \\
\hline Viscum capitellatum & $21.72 \pm 1.5$ & $466.9 \pm 23.93$ & $35.42 \pm 2.75$ & $17.8 \pm 1.08$ & $79.24 \pm 8.77 \mathrm{~ns}$ & $21.33 \pm 2.23$ \\
\hline Viscum trilobatum & $22.04 \pm 1.12$ & $498.05 \pm 26.53$ & $38.17 \pm 3.36$ & $17.62 \pm 0.92$ & $81.62 \pm 10.14 \mathrm{~ns}$ & $22.03 \pm 1.64$ \\
\hline
\end{tabular}

Values are expressed as mean $\pm \mathrm{SD} ; \mathrm{n}=6$. Values were statistically analysed using one-way ANOVA followed by Dunnett multiple comparison test. ns Not significant $(\mathrm{p}>0.05),{ }^{*} \mathrm{p}<0.05 ;{ }^{* * *} \mathrm{p}<0.001$ significantly.

Table 6: Effect of Viscum species on IL-6and CRP levels during carrageenan induced paw edema formation

\begin{tabular}{|c|c|c|c|c|c|c|}
\hline & \multicolumn{3}{|c|}{ IL-6 (pg/ml) } & \multicolumn{3}{|l|}{ CRP (pg/ml) } \\
\hline & Initial & $3^{\text {rd }} \mathbf{h}$ & $24^{\text {th }} h$ & Initial & $3^{\text {rd }} \mathbf{h}$ & $24^{\text {th }} h$ \\
\hline Control & $32.25 \pm 1$ & $338.96 \pm 6.3$ & $38.6 \pm 3.2$ & $535.4 \pm 4$ & $1171.6 \pm 26.4$ & $731.9 \pm 25.4$ \\
\hline Viscum oriental( $3.3 \mathrm{mg} / \mathrm{kg} \mathrm{b.} \mathrm{wt)}$ & $30.9 \pm 0.3$ & $356.9 \pm 6^{*}$ & $42.5 \pm 4.8^{\mathrm{ns}}$ & $540.2 \pm 2$ & $983.2 \pm 32.5^{*}$ & $659.5 \pm 21.4^{* * *}$ \\
\hline Viscum nepalense ( $3.3 \mathrm{mg} / \mathrm{kg} \mathrm{b.} \mathrm{wt)}$ & $31.66 \pm 4$ & $146.6 \pm 4^{* * *}$ & $38.2 \pm 4.2^{\text {ns }}$ & $529.3 \pm 1$ & $730.6 \pm 29.5^{* * *}$ & $542.1 \pm 17.8^{* * *}$ \\
\hline Viscum ramossimim $(3.3 \mathrm{mg} / \mathrm{kg}$ b. wt $)$ & $30.2 \pm 2$ & $213.9 \pm 5^{* * *}$ & $37.5 \pm 5.6^{\mathrm{ns}}$ & $530 \pm 2.9$ & $838.8 \pm 24.7^{* * *}$ & $583.9 \pm 19.5^{* * *}$ \\
\hline Viscum angulatum $(16 \mathrm{mg} / \mathrm{kg} \mathrm{b} . \mathrm{wt})$ & $31.32 \pm .5$ & $195.1 \pm 6^{* * *}$ & $36.1 \pm 3.6^{\mathrm{ns}}$ & $535.4 \pm 2$ & $758.4 \pm 21.8^{* * *}$ & $555.6 \pm 16.8^{* * *}$ \\
\hline Viscum Capitellatum $(16 \mathrm{mg} / \mathrm{kg})$ & $43.88 \pm 5.86$ & $267.84 \pm 16.29$ ns & $44.05 \pm 3.89$ & $526.19 \pm 31.22$ & $1101.51 \pm 135.8^{\mathrm{ns}}$ & $707.18 \pm 33.75$ \\
\hline Viscum Trilobatum $(8 \mathrm{mg} / \mathrm{kg})$ & $42.29 \pm 4.02$ & $273.61 \pm 15.01^{\mathrm{ns}}$ & $45.08 \pm 5.39$ & $520.51 \pm 34.51$ & $1179 \pm 80.27^{\mathrm{ns}}$ & $732.53 \pm 49.86$ \\
\hline
\end{tabular}

IL-6 and CRP levels were expressed in pg/ml. Values are expressed as mean \pm SD; $n=6$. Values were statistically analysed using one-way ANOVA followed by Dunnett multiple comparison test. ns-Not significant $(\mathrm{p}>0.05),{ }^{* * *} \mathrm{p}<0.001$ significantly.

Table 7: Effect of Viscum species on nitric oxide levels during carrageenan induced paw edema formation

\begin{tabular}{|c|c|c|c|}
\hline & Initial & $3^{\text {rd }} \mathbf{h}$ & $24^{\text {th }} h$ \\
\hline Control & $23.4 \pm 0.26$ & $66.78 \pm 4.8$ & $29.42 \pm 2.3$ \\
\hline Viscum orientale $(3.3 \mathrm{mg} / \mathrm{kg} \mathrm{b.} \mathrm{wt)}$ & $22.4 \pm 0.53$ & $67.7 \pm 3.2^{\mathrm{ns}}$ & $28.84 \pm 2.14^{\mathrm{ns}}$ \\
\hline Viscum nepalense (3.3 mg/kg b. wt) & $21.2 \pm 0.63$ & $39.69 \pm 4.8^{* * *}$ & $21.97 \pm 2.3^{* *}$ \\
\hline Viscum ramossimium $(3.3 \mathrm{mg} / \mathrm{kg} \mathrm{b} . \mathrm{wt})$ & $22.63 \pm .92$ & $58.47 \pm 3.1^{* * *}$ & $22.77 \pm 3.4^{* *}$ \\
\hline Viscum angulatum $(16 \mathrm{mg} / \mathrm{kg} \mathrm{b.} \mathrm{wt)}$ & $22 \pm 0.53$ & $46.15 \pm 2.7^{* * *}$ & $21.96 \pm 3.8^{* *}$ \\
\hline Viscum capitellatum $(16 \mathrm{mg} / \mathrm{kg})$ & $22.27 \pm 1.35$ & $57.59 \pm 6.27^{\mathrm{ns}}$ & $22.34 \pm 1.01$ \\
\hline Viscum trillobatum & $21.98 \pm 1.57$ & $63.98 \pm 6.42^{\mathrm{ns}}$ & $23.88 \pm 1.86$ \\
\hline
\end{tabular}

Nitric oxide levels were expressed in pg/ml. Values are expressed as mean \pm SD; $n=6$. Values were statistically analysed using one-way ANOVA followed by Dunnett multiple comparison test. ns-Not significant $(\mathrm{p}>0.05),{ }^{* *} \mathrm{p}<0.01 ;{ }^{* * *} \mathrm{p}<0.001$ significantly 
However as in the case of inflammation both $V$. capitallatum and $V$. trilobatum extracts did not produce any significant reduction in the pro-inflammatory cytokine levels.

\section{DISCUSSION}

Short term cytotoxic activity of all plants of Viscaceae were studied using DLA and Ehrlich ascites carcinoma cells by trypan blue dye exclusion method. Results showed profound cytotoxicity towards both DLA and EAC cells. We also checked the cytotoxic effect of $V$. orientale, $V$. nepalense, $V$. ramosissimum and $V$. angulatum, $V$. capitallatum and $V$. trillobatum against breast cancer cell lines such as MCF-7, MDA-MB-231 and SkBR3 cell lines. MCF-7 is a human breast adenocarcinoma cell line and is useful for in vitro breast cancer studies because the cell line has retained several ideal characteristics particular to the mammary epithelium. These included the ability of MCF-7 cells to process estrogen, in the form of estradiol, via estrogen receptors in the cell cytoplasm. This makes the MCF-7 cell line an estrogen receptor (ER) positive control cell line. Triple-negative breast cancers, to date is the highest risk breast neoplasia, so MDA-MB-231, a triple-negative (ER-ve, PR-ve, no HER2 over expression) human breast adenocarcinoma cell line was used. SkBR3 is a human breast adenocarcinoma cell line that overexpresses the HER 2 gene product and has been widely used in studies seeking to overcome Herceptin resistance to HER2overexpressing breast cancer. Four Viscum species plant extracts showed cytotoxicity towards all the four types of human breast cancer cell lines. However $V$. capitellatum and V. trillobatum were less toxic. Cytotoxicity studies on normal cell like Vero cells showed that $V$. orientale, $V$. nepalense and $V$. ramosissimum, $V$. capitallatum were slightly cytotoxic to normal cells. $V$. angulatum and $V$. trilobatum showed selective cytotoxicity towards transformed cells and was non toxic to normal cells.

The in vivo tumoricidal activity of $V$. orientale, $V$. nepalense, $V$. ramosissimum, $V$. angulatum, $V$. capitallatum and $V$. trilobatum were evaluated using the Ehrlich Ascites Carcinoma (EAC) induced ascites tumor model and the Dalton's Lymphoma Ascites (DLA) cell induced solid tumor model. EAC is referred to as an undifferentiated carcinoma and has a rapid growth rate. The present study revealed that all six plants possessed considerable anti-tumor activity against EAC cell induced ascites tumor. However, Viscum angulatum showed the highest anti-tumor activity. DLA is a transplantable and poorly differentiated malignant tumor cell. Four Viscaceae plant extracts were also found to reduce the solid tumor induced by DLA cells with Viscum angulatum showing the highest activity. V. capitallatum and V. trillobatum were non-active.

Inflammation acts at all stages of tumorigenesis. It contributes to tumor initiation through mutations, genomic instability, and epigenetic modifications. Inflammation activates tissue repair responses, induces proliferation of premalignant cells, and enhances their survival. Inflammation also stimulates angiogenesis, causes localized immunosuppression, and promotes the formation of a hospitable microenvironment in which premalignant cells can survive, expand, and accumulate additional mutations and epigenetic changes [33]. Carrageenan consists of linear sulfated polysaccharides that are extracted from rededible seaweeds. Carrageenan-induced paw edema in mice is a widely used test to determine anti-inflammatory activity. Carrageenan stimulates the release of TNF- $\alpha$, which, in turn, induces IL- $1 \beta$ and IL-6, thus stimulating the production of COX- 2 products. The present study revealed that treatment with different Viscum extracts showed a significant reduction in paw edema formation and elevated proinflammatory cytokine levels induced by carrageenan. Dextran is another inflammatory agent. All Viscum extracts except $V$. capitallatum and $V$. trillobatum showed a significant antiinflammatory effect against the dextran induced inflammatory model.

Out of the six plants studied, Viscum angulatum was found to be most promising as it showed significant anti-tumor and antiinflammatory activity combined with its non-toxicity. Presently we do not know the active ingredients responsible for the activity of $V$. angulatum. Lin et al. reported the presence of several flavanoid and phenolic glycosides in $V$. angulatum which may be contributing to the anti-tumour activity of this species [34]. Further studies on the molecular mechanism behind the anticancer effects of these plants needs to be explored.

\section{CONCLUSION}

Data indicated that out of six species studied four of the plants were highly toxic to animals. However at non-toxic doses they could reduce animal tumours and inhibit the inflammation induced the carragenine and dextran. $V$. angulatum was nontoxic and it showed significant antitumour and anti-inflammatory activity.

\section{ACKNOWLEDGEMENT}

This work was financially supported by National Medicinal Plants Board, Department of AYUSH, Ministry of Health and Family Welfare, Government of India.

\section{AUTHORS CONTRIBUTION}

Dr. Shivamurthy G. R. helped in collection of the plants used in the study. Dr. Girija Kuttan and Dr. Ramadasan Kuttan are the main investigators of this project.

\section{CONFLICT OF INTERESTS}

The authors report no declarations of interest.

\section{REFERENCES}

1. Anshutz EP. Viscum album New Old and Forgotten Remedies; 1961. p. 600-2.

2. Steiner R. Spiritual Science and Medicine. Rudolf Steiner Publishing Company, London; 1920. p. 394.

3. Leroi R. Clinical experience with mistletoe preparation Iscador. Vittoriq Klostermann, Frankfart; 1975.

4. Kuttan G, Vasudevan DM, Kuttan R. Effect of a preparation from Viscum album on tumor development in vitro and in mice. J Ethnopharmacol 1990;29:35-41.

5. Kuttan G, Menon LG, Antony S, Kuttan R. Anticarcinogenic and antimetastatic activity of lscador. Anticancer Drugs 1997;8:815-6.

6. Antony S, Kuttan R, Kuttan G. Effect of Viscum album in the inhibition of lung metastasis in mice induced by B16F10 melanoma cells. J Exp Clin Cancer Res 1997;16:159-62.

7. Kuttan G, Kuttan R. Reduction of leukopenia in mice by "Viscum album" administration during radiation and chemotherapy. Tumori 1993;79:74-6.

8. Franz H. Mistletoe lectins and A and B changes. Oncology 1986;43 Suppl 1:23-34.

9. Samuelson G, Petterson BM. The amino acid sequence of Viscotoxin B from European Mistletoe. Eur J Biochem 1971;21:86-9.

10. Khwaja TA, Dias CB, Pentecoast S. Recent studies on the anticancer activities of Mistletoe (Viscum album) and its alkaloids. Oncology 1986;43 Suppl 1:42-50.

11. Jordan E, Wagner H. Structure and properties of polysaccharide from Viscum album L. Oncology 1986;43 Suppl 1:8-15.

12. Harmsma M, Ummelen M, Dignef W, Tusenius KJ, Ramaekers FC. Effects of mistletoe (Viscum album L.) extracts Iscador on cell cycle and survival of tumor cells. Arzneim Forsch 2006;56:474-82.

13. Park WB, Lyu SY, Kim JH, Choi SH, Chung HK, Ahn SH, et al. Inhibition of tumor growth and metastasis by Korean mistletoe lectin is associated with apoptosis and antiangiogenesis. Cancer Biother Radiopharm 2001;16:439-47.

14. Elluru SR, Van Huyen JP, Wootla B, Delignat S, Prost F, Negi VS, et al. Tumor regressive effects of Viscum album preparationsexploration of immunomodulatory mechanisms. Medicina 2007;67:85-9.

15. Bussing A. Immune modulation using mistletoe (Viscum album L.) extracts Iscador. Arzneim Forsch 2006;56:508-15.

16. Liu B, Bian HJ, Bao JK. Plant lectins: potential antineoplastic drugs from bench to clinic. Cancer Lett 2010;287:1-12.

17. Engdal S, Nilsen OG. Inhibition of P-glycoprotein in Caco-2 cells: effects of herbal remedies frequently used by cancer patients. Xenobiotica 2008;38:559-73.

18. Ostermann T, Raak C, Bussing A. Survival of cancer patients treated with mistletoe extract (Iscador): a systematic literature review. BMC Cancer 2009; 9:451. 
19. Grossarth-Maticek R, Ziegler R. Randomised and nonrandomised prospective controlled cohort studies in matchedpair design for the long-term therapy of breast cancer patients with a mistletoe preparation (Iscador): a re-analysis. Eur J Med Res 2006;11:485-95.

20. Bussing A, Raak C, Ostermann T. Quality of life and related dimensions in cancer patients treated with mistletoe extract (Iscador): a meta-analysis. eCAM 2012;212-19. Doi:10.1155/ 2012/219402

21. Gil Bar-Sela. White-berry mistletoe (Viscum album L.) as complementary treatment in cancer: does it help. Eur J Int Med 2011;3:55-62.

22. Kumar S, Sangeetha B, Rajalekshmi M, Muralidhar R, Yashovarma B. Pharmacognostical and phytochemical studies on dyer's oleander mistletoe, Viscum orientale Wild. Indian J Nat Prod Resour 2013;4:260-9.

23. Murali M, Puneetha GK, Thriveni MC, Niranjan MH Shivamurthy GR, Niranjana SR, et al. Phytochemical screening and antioxidant activity of hemi-parasitic Indian mistletoe Viscum nepalense Sprengel. J Pharm Res 2011;4:348-50.

24. Jadhav RB, Bhatnagar SP, Surana SJ. Diuretic activity of squamate mistletoe, Viscum angulatum. Pharm Biol 2010;48:417-21.

25. Moldeus P, Hogberg J, Orrhenius S, Fleischer SP. In: Methods in Enzymology. New York: Academic press; 1978;52:60-71.
26. Cole SP. Rapid chemo sensitivity testing of human lung tumor cells using MTT assay. Cancer Chemoth Pharmacol 1986;17:256-60.

27. Campling BG, Phym J, Barker HM, Cole SP, Lam YM. Chemo sensitivity testing of small cell lung cancer using the MTT assay. Br J Cancer 1991;63:75-83.

28. Kuttan R, Bhanumathy P, Nirmala K, George MC. Possible anticancer activity of turmeric. Cancer Lett 1985;29:197-202.

29. Atia MA, Weiss DW. Immunology of spontaneous mammary carcinomas in mice. Acquired tumor resistance and enhancement in strain A mice infected with mammary tumor virus. Cancer Res 1966;26:1887-900.

30. Winter CA, Risly EA, Nuss CW. Carrageenan induced paw edema in hind paw of the rats-an assay for its antiinflammatory drugs. Proc Soc Exp Biol Med 1962;11:544-7.

31. Maity TK, Mandal SC, Mukherjee PK. Studies on antiinflammatory effect of Cassia tora leaf extract (Fam. Leguminosae). Phytother Res 1988;12:221-4.

32. Green LC, Wagner DA, Glogowski J. Analysis of nitrate and nitrite and (15-N) nitrite in biological fluids. Anal Biochem 1982;126:131-8.

33. Grivennikov SI, Greten FR, Karin M. Immunity, Inflammation, and Cancer. Cell 2010;140:883-99.

34. Lin JH, Chiou YN, Lin YL. Phenolic glycosides from Viscum angulatum. J Natl Prod 2002;65:638-40. 